\title{
SPACIAL VARIABILITY AND SAMPLING DENSITY OF CHEMICAL ATTRIBUTES IN ARCHAEOLOGICAL BLACK EARTH AND NATIVE FOREST SOIL IN MANICORÉ, AM
}

\author{
Ivanildo Amorim de Oliveira ${ }^{1}$, José Marques Junior ${ }^{2}$, Milton César Costa Campos ${ }^{3}$, \\ Renato Eleotério de Aquino ${ }^{1}$, Diego Silva Siqueira ${ }^{4}$, Ludmila de Freitas ${ }^{4}$

\footnotetext{
${ }^{1}$ Agronomist Engineer, M.Sc, FCAV/UNESP, Jaboticabal, SP, Brasil - ivanildoufam@gmail.com; aquino.rea@ gmail.com. ${ }^{3}$ Agronomist Engineer, Dr., UFAM/IEAA, Humaitá, AM, Brasil - mcesarsolos@ gmail.com.
} \\ ${ }^{2}$ Agronomist Engineer, Dr., FCAV/UNESP, Jaboticabal, SP, Brasil - marques@ fcav.unesp.br; diego_silvasiqueira@yahoo.com.br. \\ ${ }^{4}$ Biologist, M.Sc., FCAV/UNESP, Rio Claro, SP, Brasil - ludmilafreitas@ gmail.com.
}

Received: 26/11/2012 - Accepted for publication: 04/04/2014

\begin{abstract}
Considering the lack of information about spatial behavior of the soil attributes in areas of archaeological black earth and native forest, the objective of this study was to evaluate the spatial variability of chemical attributes and determine the sampling density in soil with archaeological black earth and native forest in the region of Manicoré, AM. The study was conducted in a rural property located in the community of Santo Antônio do Matupi, at the margins of BR 230, Trans-amazon highway, in the region of Manicoré, AM. In these areas were established grids of $70 \mathrm{~m} \times 70 \mathrm{~m}$, with regular spacing of $10 \times 10 \mathrm{~m}$, totaling 64 points, then soil samples were collected at a depth of 0.0 $0.20 \mathrm{~m}$ and $0,40-0,60 \mathrm{~m}$. Chemical attributes were determined (pH, OM, P, K, Ca, Mg, SB, CTC, $\mathrm{V} \%$ and $\mathrm{H}+\mathrm{Al}$ ). Data were analyzed using descriptive statistical techniques and geostatistics. Sampling density was determined basing on CV and on the range of the semivariograms. It was verified that the studied attributes showed spatial variability and the area of archaeological black earth presented greater spatial variability than the native forest. Its greater sampling density was determined basing on the range of the adjusted semivariograms.

Keywords: Indian black earth; attributes of soil; geostatistics.
\end{abstract}

\section{Resumo}

Variabilidade espacial e densidade amostral de atributos químicos em solo de terra preta arqueológica e floresta nativa em Manicoré, AM. Considerando a falta de informações sobre o comportamento espacial dos atributos do solo em áreas de terras pretas arqueológicas ou terras pretas de índio e floresta, o objetivo deste trabalho foi avaliar a variabilidade espacial de atributos químicos e determinar a densidade amostral em solo com terra preta arqueológica e floresta nativa na região de Manicoré, AM. O estudo foi realizado em uma propriedade rural localizada na comunidade de Santo Antônio do Matupi, às margens da BR 230, rodovia Transamazônica, região de Manicoré, AM. Nestas áreas foram estabelecidas malhas de $70 \mathrm{~m}$ x $70 \mathrm{~m}$, com espaçamento regular de $10 \times 10 \mathrm{~m}$ totalizando 64 pontos e em seguida, coletadas amostras de solos na profundidade de 0,0-0,20 m e 0,40-0,60 m. Foram determinados os atributos químicos ( $\mathrm{pH}$ em água, $\mathrm{MO}, \mathrm{P}, \mathrm{K}, \mathrm{Ca}, \mathrm{Mg}, \mathrm{SB}, \mathrm{CTC}, \mathrm{V} \%$ e $\mathrm{H}+\mathrm{Al}$ ). Os dados foram analisados utilizando-se técnicas de estatística descritiva, geoestatística e determinado a densidade amostral com base no CV e no alcance dos semivariogramas. Verificou-se que os atributos estudados apresentaram variabilidade espacial e a área de terra preta arqueológica apresentou maior variabilidade espacial em relação à floresta nativa, apresentando maior densidade amostral baseados no alcance dos semivariogramas ajustados.

Palavras-chave: Terra preta de índio; atributos do solo; geoestatística.

\section{INTRODUCTION}

The southern region of Amazonas is characterized by great soil variability, represented by Acrisols, Latosols, Cambisols, Neosols, Plintosols and Spodosols (CAMPOS, 2009) and in some areas of the region all these soils are characterized by the peculiar presence of an anthropic A horizon, known as Archaeological Black Earths (ABE), or Indian Black Earths (IBE). Those are soils with great natural fertility, found in the whole Amazon region (PETERSEN et al., 2001; LEHMANN et al., 2003; GLASER 
et al., 2004; GLASER, 2007; WOODS et al., 2009), and normally associated to water sources or to higher lands. Their peculiar characteristics are the darkish color and the presence of ceramic and/or lithic fragments, embedded in the matrix of the surface horizons (KAMPF; KERN, 2005).

In contrast with these soil characteristics, adjacent forests with low fertility soils have an important role in the improvement of nutritional quality and physical characteristics of the soil attributes. The study of these attributes becomes essential when rational management, sustainable productivity and prediction of forest ecosystems are the desired objectives, since both forest and soil are interconnected (WOJCIECHOWSKI et al., 2009).

Seen in these terms, the different behavior of soil attributes in different landscape locations may be understood by the characterization of their spatial variability. This can be achieved using geostatistical techniques, which help to identify similarities between locations of the landscape. This spatial knowledge of the attributes of a soil in a determined area is important for the evaluation of its environmental quality, as it is important to define the necessary sampling density to achieve a reliable characterization (CARVALHO et al., 2010; VIEIRA, 2000).

Those sampling strategies are important to map the spatial variability of soils and their attributes, because creation of more consistent maps is possible only starting from the mentioned modeling techniques. Besides, there are studies indicating that the correct characterization of IBEs according to the taxonomic classification of the Brazilian System of Soil Classification (EMPRESA BRASILEIRA DE PESQUISA AGROPECUARIA (EMBRAPA), 2013), whose parameters are established by a committee, will require some modifications to this classification system.

Thus, information on variability of the attributes may help this committee to make these changes. Minasny and Mcbratney (2007) also propose the use of numeric classification models for a better mapping and identification of these soil limits and their attributes in field.

In this context, the great difficulty encountered during studies on soil spatial variability is the determination of the ideal sampling density, which in some situations hinders the use of precision agriculture techniques. Thus, studies on soil sampling methods, with the intent to subsidize the use and recommendation of these techniques in different environments, has been a constant challenge for researchers (WEBSTER; OLIVER, 1990; VAN GROENIGEN et al., 1999; LARK, 2000, MONTANARI et al., 2005). Works like Souza et al. (2006), developed on Latisols and considering the soil-embossment aspects and using sampling density, showed to be efficient to estimate the chemical attributes, reducing the minimum number of samples to be collected.

Objective of this study was to determine spatial variability and sampling density of the chemical attributes, in Indian Black Earths and adjacent soils, of a native forest in the municipality of Manicoré, AM.

\section{MATERIAL AND METHODS}

The study was conducted in an estate, located in the southern Amazonas state, close to the community of Santo Antonio de Matupi, alongside the Transamazon Highway BR 230 in the region of Manicoré, AM. The IBE area below a cultivated Red Acrisol, with corn cultivations, is located in the geographical coordinates $07^{\circ} 55^{\prime} 02,1^{\prime \prime} \mathrm{S}$ and $61^{\circ} 31^{\prime} 45,2^{\prime \prime} \mathrm{W}$, at an average altitude of $102 \mathrm{~m}$. Adjacent soil (Red Acrisol) is near the IBE area, under a native forest located in the geographical coordinates $7^{\circ} 54^{\prime} 44,5^{\prime \prime} \mathrm{S}$ and $61^{\circ} 31^{\prime} 44,7^{\prime \prime} \mathrm{W}$, at an average altitude of $140 \mathrm{~m}$ above sea level (Figure 1).

The original material was generated by alterations in granites of Rondonia type, of the Early PreCambrian geological period, and is formed by colluvial sediments, laying in the lower parts of the landscape, known as tertiary clay plains (BRASIL, 1978). Climate of the region, according to Köppen classification, is tropical rainy, with a short dry period (Am) and temperature variations between $25^{\circ} \mathrm{C}$ and $27^{\circ} \mathrm{C}$. Rainfall is between 2,250 and $2,750 \mathrm{~mm}$, with concentrations in the period from October to June (BRASIL, 1978).

Two grids of $70 \mathrm{~m} \times 70 \mathrm{~m}$ were established, with approximately 0.49 hectares area, being one grid per each area, and soil was sampled with regular 10 by $10 \mathrm{~m}$ spacing between crossing points, totalizing 64 sampling points per each grid (Figure 1). These points were georeferenced with a Garmin Etrex GPS equipment (South American 69). Next, soil samples collection took place at $0.0-0.20 \mathrm{~m}$ and $0.40-0.60 \mathrm{~m}$ depth, to determine the chemical attributes, totalizing 128 soil samples from each grid. Particle size characterization values of the IBE area were $434.14 \mathrm{~g} \mathrm{~kg}^{-1}$ of sand, $444.36 \mathrm{~g} \mathrm{~kg}^{-1}$ of silt e $121.50 \mathrm{~g} \mathrm{~kg}^{-1}$ of clay at $0.0-0.20 \mathrm{~m}$ depth, and $426.26 \mathrm{~g} \mathrm{~kg}^{-1}$ of sand, $297.99 \mathrm{~g} \mathrm{~kg}^{-1}$ of silt and $275.75 \mathrm{~g} \mathrm{~kg}^{-1}$ of clay at $0.40-$ 
$0.60 \mathrm{~m}$ depth. The adjacent soil under native forest gave $358.81 \mathrm{~g} \mathrm{~kg}^{-1}$ of sand, $313.24 \mathrm{~g} \mathrm{~kg}^{-1}$ of silt and $327.94 \mathrm{~g} \mathrm{~kg}^{-1}$ of clay at $0.0-0.20 \mathrm{~m}$ depth, and $251.35 \mathrm{~g} \mathrm{~kg}^{-1}$ of sand, $355.71 \mathrm{~g} \mathrm{~kg}^{-1}$ of silt and $392.94 \mathrm{~g}$ $\mathrm{kg}^{-1}$ of clay at $0.40-0.60 \mathrm{~m}$ depth.

The following chemical analyses were conducted on the soil samples, according to methodologies suggested by EMBRAPA (2011): 1) exchangeable calcium, magnesium and aluminum, extracted by $\mathrm{KCl}$; 2) available potassium and phosphorus extracted by Mehlich-1;3) potential acidity $(\mathrm{H}+\mathrm{Al})$ extracted by $\mathrm{pH} 7.0$ calcium acetate solution. Basing on results of the chemical analyses, the Sums of Bases (SB), cation exchange capacity (T) and saturation by bases (V\%), were then calculated.

Having obtained the analytic results, evaluation of chemical attributes of IBE and native forest adjacent soils began initially with the explorative analysis of data, calculating mean, median, variance, coefficient of variation, asymmetry coefficient, coefficient of kurtosis and test of normality. The Coefficient of Variation (CV) was calculated basing on the criterion of Warrick and Nielsen (1980), which classifies its value low if $\mathrm{CV}<12 \%$, medium from $12 \%$ to $60 \%$ and high if $\mathrm{CV}>60 \%$. Hypothesis of normality was verified by the Kolmogorov-Smirnov test, using the statistical software Minitab 14.

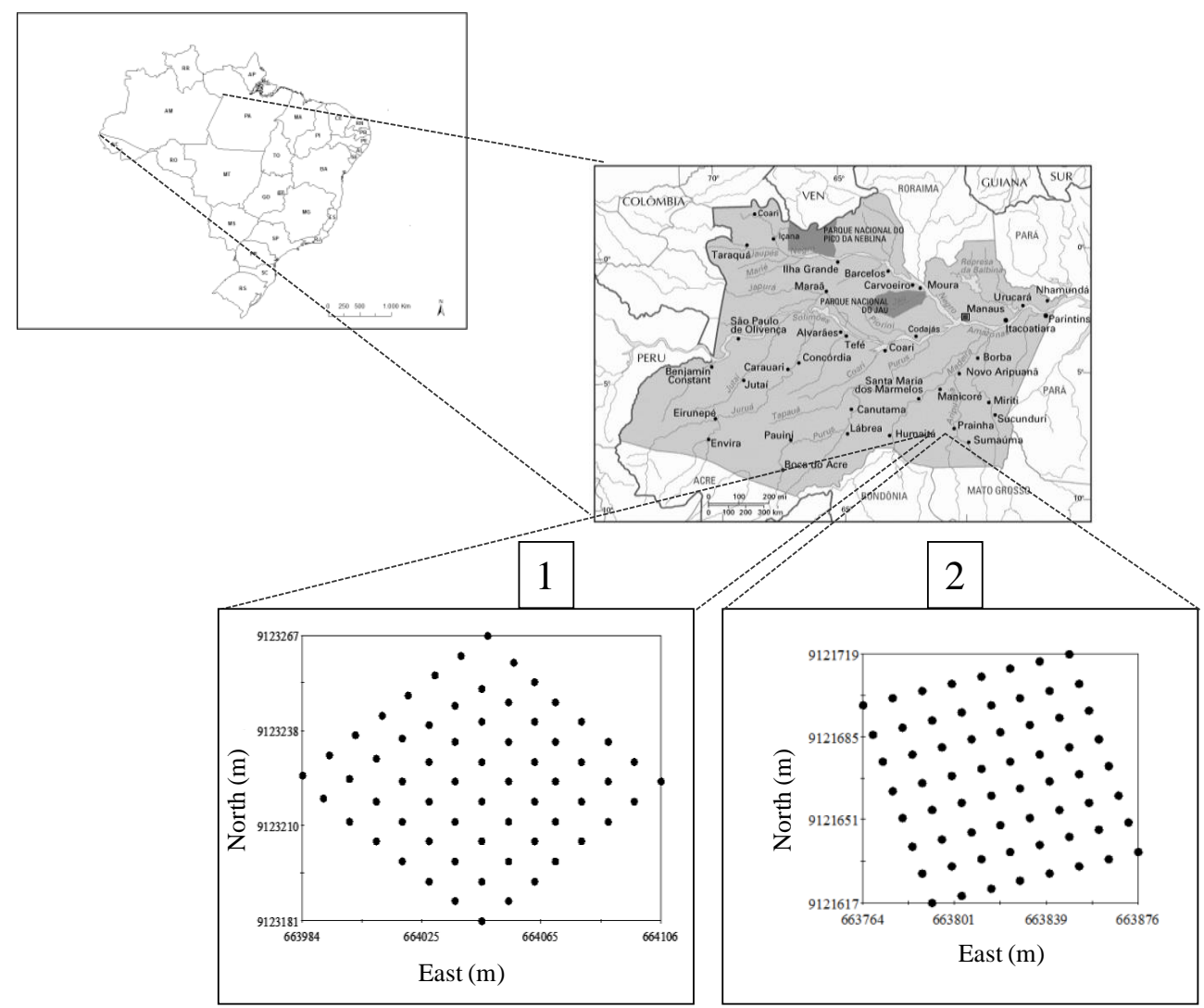

Figure 1. Location of areas: 1: Area with adjacent soil under forest; 2: Area with corn cultivated IBE.

Figura 1. Localização das áreas: 1: Área com solo adjacente sob floresta; 2: Área com TPI cultivada com milho.

The $\mathrm{pH}$ was determined with a potentiometric method, using the ratio soil:water of 1:2.5, according to EMBRAPA (2011). Organic carbon was determined by the method of Walkley-Black, modified by Yeomas and Brenner (1988), and the organic matter was estimated basing on the values of organic carbon

To characterize the spatial variability, a geostatistical analysis based on studies by Matheron (1963), Vieira et al. (1983) and Isaaks et al. (1989), was used. The experimental semivariogram, under the "intrinsic hypothesis" theory, was estimated by the following equation: 


$$
\hat{\gamma}(h)=\frac{1}{2 N(h)} \sum_{i=1}^{N(h)}\left[Z\left(x_{i}\right)-Z\left(x_{i}+h\right)\right]^{2}
$$

where: $\gamma(\mathrm{h})=$ value of semivariance for a given $\mathrm{h}$ distance

$\mathrm{N}(\mathrm{h})=$ number of pairs involved into calculation of the semivariance

$\mathrm{Z}\left(\mathrm{x}_{\mathrm{i}}\right)=$ value of the attribute $\mathrm{Z}$ in a given position $\mathrm{x}_{\mathrm{i}}$;

$\mathrm{Z}\left(\mathrm{x}_{\mathrm{i}}+\mathrm{h}\right)=$ value of the attribute $\mathrm{Z}$ at a distance $\mathrm{h}$ from the $\mathrm{x}_{\mathrm{i}}$ position.

Coefficients of the theoretical model for the semivariogram are defined from the adjusting of a mathematical model to the calculated $\gamma^{\wedge}(\mathrm{h})$ values (nugget effect, $\mathrm{C}_{0}$; structural variance, $\mathrm{C}_{1} ;$ sill, $\mathrm{C}_{0}+\mathrm{C}_{1}$; and range, a). Nugget effect is the value of the semivariance at zero distance and represents the component of random variation; sill is the value of semivariance where the curve stabilizes above a constant value; range is the distance from the origin to where sill reaches stable values, expressing the distance limit above which samples are not spatially correlated any more (VIEIRA et al., 1983; TRANGMAR et al., 1985). Semivariograms were analyzed using the $\mathrm{GS}^{+}$program (ROBERTSON, 1998), to determine if spatial dependence existed or not. In case of doubts between more models for the same semivariogram, the best $\mathrm{R}^{2}$ was considered (coefficient of determination).

To analyze the degree of spatial dependence between the studied variables (Table 2), the classification method proposed by Cambardella et al. (1994) was used. In this method, values of $\left[\left(\mathrm{C}_{0} /\left(\mathrm{C}_{0}+\mathrm{C}_{1}\right)\right]\right.$ lower than $25 \%$ are considered with strong spatial dependence, values of $\left[\left(\mathrm{C}_{0} /\left(\mathrm{C}_{0}+\mathrm{C}_{1}\right)\right]\right.$ between 25 and $75 \%$ indicate a moderate spatial dependence and values of $\left[\left(\mathrm{C}_{0} /\left(\mathrm{C}_{0}+\mathrm{C}_{1}\right)\right]\right.$ above $75 \%$ are considered with weak spatial dependence.

The number of sub-samples needed to create a composed sample and estimate mean value of the variables was determined basing on the coefficient of variation using the formula described by Cline (1944):

$$
\mathrm{n}=\left(\frac{\mathrm{t}_{\alpha} \cdot \mathrm{CV}}{\mathrm{D}}\right)^{2}
$$

where: $\mathrm{n}=$ minimum number of samples to define a sampling mesh;

t $\alpha=$ value of Student's t distribution (at $95 \%$ of probability);

$\mathrm{CV}=$ coefficient of variation

$\mathrm{D}=$ percentage of variance starting from mean value $(5 \%)$.

The number of sub-samples was also determined basing on the range values obtained in the geostatistical analysis, according to equation 3.

$$
\mathbf{N}=\frac{\mathrm{A}}{\left(\mathrm{a}^{2}\right) / 10000}
$$

where: $\mathrm{N}=$ minimum number of samples needed to determine a sampling grid ;

$\mathrm{A}=$ total area in hectares

$\mathrm{a}=$ range of the semivariogram in meters

\section{RESULTS AND DISCUSSIONS}

Mean values and median values of almost all the studied variables, as it can be observed, are very close each other, highlighting that variables are approximating to a normal distribution and indicating that data follow symmetrical distributions (Table 1 and 2). These values are justified by asymmetry and kurtosis values close to zero. Exceptions can be observed for $\mathrm{K}(0.0-0.20 \mathrm{~m}$ and $0.40-$ $0.60 \mathrm{~m})$ and $\mathrm{Mg}(0.40-0.60 \mathrm{~m})$ in the IBE area, and $\mathrm{H}+\mathrm{Al}, \mathrm{K}, \mathrm{Mg}, \mathrm{SB}(0.0-0.20 \mathrm{~m}), \mathrm{Ca}, \mathrm{K}, \mathrm{P}$ and V\% $(0.40-0.60 \mathrm{~m})$ in the adjacent soil under forest, which presented mean and median values slightly distant, highlighting that in this case they may be influenced by extreme values. 
Consequently, values of asymmetry and kurtosis farer from zero can be observed, affirming the fact that these variables are not following an asymmetry or are not following a standard curve of distribution. About data of asymmetry and kurtosis, Cortez et al. (2011) affirm that the closer data are to zero, the higher is their normality, and thus they are not necessary for application of geostatistics. However, information about these parameters make the "visual adjustment" easier.

Comparing mean values of the chemical attributes of Archeological Black Earths with adjacent soil under native forest, differences are observable between attributes in different soils (Table 1 and 2). Values of chemical attributes of IBE are, in general, far greater than the one of soils under native forest, highlighting a greater fertility and better quality of these soils. Greater Organic Matter content (OM), Sum of Bases (SB) and saturation per bases values (V\%) are observable in the Archeological Black Earths $(\mathrm{ABE})$, together with greater values of the attributes $\mathrm{pH}, \mathrm{P}, \mathrm{Ca}, \mathrm{Mg}$ and greater $\mathrm{T}$; on the other hand, forest present greater potential acidity in both depths and greater $\mathrm{K}$ at $0.40-0.60 \mathrm{~m}$ depth, with 74.92 , 59.55 and $1.39 \mathrm{mmol} \mathrm{kg}^{-1}$, respectively.

This fact explains the great fertility of ABEs compared to adjacent soils, since according to Kern and Kämpf (1989), Lehmann et al. (2003) and Glaser (2007), these soils generally present great natural fertility, with great $\mathrm{P}, \mathrm{Ca}, \mathrm{Mg}, \mathrm{Zn}, \mathrm{Mn}$ contents, and with great content of stable organic matter. On the other hand, Cunha et al. (2007) affirm that the great natural fertility of these soils is strongly related to the molecular characteristics of the alkaline soluble fraction of the organic carbon, and these authors found that A horizons of anthropogenic soils of the Amazons presented greater total carbon content compared to adjacent not-anthropogenic soils, which did not present A anthropic horizon.

Table 1. Descriptive statistics of chemical attributes in archeological black earth area.

Tabela 1. Estatística descritiva dos atributos químicos em área de terra preta de índio.

\begin{tabular}{|c|c|c|c|c|c|c|c|c|c|c|c|}
\hline \multirow{2}{*}{ Attributes } & \multicolumn{11}{|c|}{ Descriptive statistics } \\
\hline & tes Un. & Mean & Median & Min. & Max & SD & Var. & $\mathrm{CV} \%$ & Kurt. & Asym. & d \\
\hline \multicolumn{12}{|c|}{ Depth $0.0-0.20 \mathrm{~m}$} \\
\hline$\overline{\mathrm{pH}}$ & $\mathrm{H}_{2} \mathrm{O}$ & 6.27 & 6.20 & 5.70 & 7.10 & 0.29 & 0.08 & 4.71 & 0.48 & 0.58 & $0.09^{\text {ns }}$ \\
\hline $\mathrm{H}+\mathrm{Al}$ & $\mathrm{mmol} \mathrm{kg}{ }^{-1}$ & 28.29 & 29.50 & 13.00 & 42.00 & 6.64 & 44.08 & 23.46 & -0.51 & -0.08 & $0.06^{\mathrm{ns}}$ \\
\hline MO & $\mathrm{g} \mathrm{dm}^{-3}$ & 68.19 & 68.00 & 29.00 & 94.00 & 13.54 & 183.33 & 19.86 & 0.31 & -0.26 & $0.06^{\mathrm{ns}}$ \\
\hline $\mathrm{P}$ & $\mathrm{mg} \mathrm{dm}^{-3}$ & 309.4 & 298.5 & 165.0 & 547.0 & 86.4 & 7465.2 & 27.93 & -0.02 & 0.53 & $0.07^{\mathrm{ns}}$ \\
\hline $\mathrm{K}$ & $\mathrm{mmol} \mathrm{kg}{ }^{-1}$ & 1.72 & 1.40 & 0.70 & 10.20 & 1.41 & 2.00 & 82.30 & 24.46 & 4.66 & $0.26^{*}$ \\
\hline $\mathrm{Ca}$ & $\mathrm{mmol} \mathrm{kg}{ }^{-1}$ & 166.02 & 164.50 & 85.00 & 214.00 & 26.72 & 714.08 & 16.10 & 0.49 & -0.51 & $0.06^{\mathrm{ns}}$ \\
\hline $\mathrm{Mg}$ & $\mathrm{mmol} \mathrm{kg}{ }^{-1}$ & 29.45 & 30.00 & 17.00 & 47.00 & 6.49 & 42.12 & 22.04 & -0.12 & 0.27 & $0.05^{\mathrm{ns}}$ \\
\hline SB & $\mathrm{mmol} \mathrm{kg}{ }^{-1}$ & 197.19 & 195.20 & 103.80 & 252.60 & 29.18 & 851.70 & 14.80 & 0.58 & -0.46 & $0.09^{\mathrm{ns}}$ \\
\hline $\mathrm{T}$ & $\mathrm{mmol} \mathrm{kg}{ }^{-1}$ & 225.49 & 227.65 & 128.80 & 274.40 & 27.74 & 769.48 & 12.30 & 1.15 & -0.61 & $0.08^{\mathrm{ns}}$ \\
\hline$\underline{\mathrm{V}}$ & $\%$ & 87.20 & 86.80 & 78.10 & 93.70 & 3.58 & 12.86 & 4.11 & -0.46 & -0.20 & $0.08^{\mathrm{ns}}$ \\
\hline \multicolumn{12}{|c|}{ Depth $0.40-0.60 \mathrm{~m}$} \\
\hline$\overline{\mathrm{pH}}$ & $\mathrm{H}_{2} \mathrm{O}$ & 5.90 & 5.90 & 5.20 & 6.8 & 0.31 & 0.090 & 5.30 & 0.77 & 0.66 & $0.11^{*}$ \\
\hline $\mathrm{H}+\mathrm{Al}$ & $\mathrm{mmol} \mathrm{kg}{ }^{-1}$ & 30.55 & 31.00 & 18.00 & 47.00 & 5.98 & 35.76 & 19.57 & 0.25 & 0.03 & $0.04^{\mathrm{ns}}$ \\
\hline MO & $\mathrm{g} \mathrm{dm}^{-3}$ & 24,11 & 22.00 & 15.00 & 39.00 & 5.34 & 28.61 & 22.19 & -0.23 & 0.67 & $0.13^{*}$ \\
\hline $\mathrm{P}$ & $\mathrm{mg} \mathrm{dm}^{-3}$ & 252,4 & 238.0 & 114.0 & 746.0 & 95.0 & 9022.5 & 37.64 & 10.69 & 2.46 & $0.15^{*}$ \\
\hline $\mathrm{K}$ & $\mathrm{mmol} \mathrm{kg}^{-1}$ & 0.74 & 0.50 & 0.20 & 8.60 & 1.04 & 1.09 & 141.74 & 53.01 & 7.02 & $0.31 *$ \\
\hline $\mathrm{Ca}$ & $\mathrm{mmol} \mathrm{kg}^{-1}$ & 75.90 & 73.00 & 39.00 & 121.00 & 17.12 & 292.96 & 22.55 & 0.68 & 0.67 & $0.08^{\mathrm{ns}}$ \\
\hline $\mathrm{Mg}$ & $\mathrm{mmol} \mathrm{kg}$ & 14.01 & 13.00 & 7.00 & 30.00 & 4.16 & 17.30 & 29.68 & 3.66 & 1.62 & $0.12^{*}$ \\
\hline SB & $\mathrm{mmol} \mathrm{kg}$ & 92.88 & 87.50 & 46.20 & 161.30 & 23.46 & 550.54 & 25.26 & 0.51 & 0.85 & $0.13^{*}$ \\
\hline $\mathrm{T}$ & $\mathrm{mmol} \mathrm{kg}^{-1}$ & 123.44 & 118.60 & 84.20 & 189.30 & 22.82 & 520.61 & 18.48 & 0.47 & 0.94 & $0.12 *$ \\
\hline $\mathrm{V} \%$ & $\%$ & 74.50 & 74.20 & 54.90 & 85.90 & 6.70 & 45.00 & 9.00 & 0.63 & -0.59 & $0.06^{\mathrm{ns}}$ \\
\hline
\end{tabular}

Un.: Unit; SD: Standard Deviation; Var.: Variance; CV: Coefficient of Variation; Kurt.: Kurtosis; Asyim.: Coefficient of Asymmetry; d: test of Normality, *significant by the test of Kolmogorov-Smirnov.

Considering the limits of coefficient of variation proposed by Warrick and Nielsen (1980), values of $\mathrm{CV}$ for the classification of $\mathrm{pH}$ and $\mathrm{V} \%$ variables in $\mathrm{ABE}$ and $\mathrm{pH}$ in forest were low $(\mathrm{CV}<$ $12 \%$ ), which can be a sign of low variability (Table 1 and 2), similarly to results found by Vieira et al. (2010) in a Red-Yellow Acrisol cultivated with grain legumes. On the opposite, K variables for ABE in 
both depths and $\mathrm{K}, \mathrm{Ca}, \mathrm{SB}$ and $\mathrm{V} \%(0.0-0.20 \mathrm{~m})$, presented greater coefficients of variation, indicating great data variability in the area $(\mathrm{CV}>60 \%)$. In this way, the other variables presented moderate variability $(12 \%<\mathrm{CV}<60 \%)$. High CV values are an estimate of greater heterogeneity of the attributes, indicating a greater variability. In this context, greater heterogeneity can be observed in the ABE area than in the native forest. According to Carvalho et al. (2003), results of the analysis of soil attributes usually present high values in the coefficient of variation.

Results referred to the Kolmogorov-Smirnov test indicated normality for the variables $\mathrm{K}(0.0-$ $0.20 \mathrm{~m}), \mathrm{pH}, \mathrm{MO}, \mathrm{P}, \mathrm{K}, \mathrm{Mg}, \mathrm{SB}, \mathrm{CTC}$ and V\% $(0.40-0.60 \mathrm{~m})$, in the IBE. On the opposite, in native forest, only the variables $\mathrm{P}$ and $\mathrm{K}(0.0-0.20 \mathrm{~m})$, and $\mathrm{pH}$ and $\mathrm{Mg}(0.40-0.60 \mathrm{~m})$ did not present normality of data. However, according to Cressie (1991), normality of data is not mandatory in geostatistics. Although normality of data is not fundamental in geostatistics, it is important to have a distribution without very long tails, which could hinder the estimates of kriging, since they are based on the mean values (ISAAKS; SRIVASTAVA, 1989).

In both the studied areas there was predominance of the adjusted spherical model, according to Isaaks and Srivistava (1989), exponential models fit better with erratic phenomena in small scale, while spherical models describe properties with great spatial continuity, or less erratic in short distances (Tables 3 and 4). Spherical and exponential models have been proposed as the most common theoretical models for soil attributes. The choice of spherical model for the majority of the attributes coincide with other works which describe this model as the one that fits better with plant and soil parameters (SALVIANO $e t$ al., 1998; BERTOLANI; VIEIRA, 2001; CAVALCANTE et al., 2007; VIEIRA et al., 2011). The majority of the adjusted models presented high values of the coefficient of determination, expressed by the values of $R^{2}$, thus justifying the models that were adjusted to the chemical variables.

Table 2. Descriptive statistics of chemical attributes in native forest area in Manicoré, AM.

Tabela 2. Estatística descritiva dos atributos químicos em área de floresta nativa em Manicoré, AM.

\begin{tabular}{|c|c|c|c|c|c|c|c|c|c|c|c|}
\hline \multirow{2}{*}{ Attribute } & \multicolumn{11}{|c|}{ Descriptive statistics } \\
\hline & ites Un. & Mean & Median & Min. & Max & SD & Var. & $\mathrm{CV} \%$ & Kurt. & Assim. & d \\
\hline \multicolumn{12}{|c|}{ Depth $0.0-0.20 \mathrm{~m}$} \\
\hline$\overline{\mathrm{pH}}$ & $\mathrm{H}_{2} \mathrm{O}$ & 3.97 & 3.90 & 3.70 & 4.60 & 0.19 & 0.03 & 4.79 & 0.25 & 0.74 & $0.11^{*}$ \\
\hline $\mathrm{H}+\mathrm{Al}$ & $\mathrm{mmol} \mathrm{kg}{ }^{-1}$ & 74.92 & 88.00 & 34.00 & 109.00 & 22.04 & 485.85 & 29.42 & -1.54 & -0.21 & $0.15^{*}$ \\
\hline MO & $\mathrm{g} \mathrm{dm}^{-3}$ & 18.66 & 20.50 & 6.00 & 31.00 & 6.58 & 43.34 & 35.29 & -1.21 & -0.28 & $0.13 *$ \\
\hline $\mathrm{P}$ & $\mathrm{mg} \mathrm{dm}^{-3}$ & 6.09 & 5.50 & 2.00 & 10.00 & 2.20 & 4.848 & 36.13 & -0.84 & 0.49 & $0.08^{\mathrm{ns}}$ \\
\hline K & $\mathrm{mmol} \mathrm{kg}{ }^{-1}$ & 1.66 & 1.50 & 0.30 & 7.80 & 1.12 & 1.248 & 67.25 & 14.13 & 2.97 & $0.14 *$ \\
\hline $\mathrm{Ca}$ & mmol kg-1 & 4.77 & 3.00 & 2.00 & 34.00 & 4.86 & 23.61 & 101.96 & 23.35 & 4.50 & $0.28 *$ \\
\hline $\mathrm{Mg}$ & $\mathrm{mmol} \mathrm{kg}{ }^{-1}$ & 2.52 & 2.00 & 1.00 & 6.00 & 1.27 & 1.61 & 50.58 & 2.53 & 1.80 & $0.15^{*}$ \\
\hline SB & $\mathrm{mmol} \mathrm{kg}{ }^{-1}$ & 8.94 & 7.05 & 3.30 & 41.20 & 6.18 & 38.15 & 69.08 & 13.08 & 3.27 & $0.27 *$ \\
\hline $\mathrm{T}$ & $\mathrm{mmol} \mathrm{kg}{ }^{-1}$ & 83.86 & 93.95 & 39.50 & 115.80 & 21.94 & 481.15 & 26.16 & -1.37 & -0.37 & $0.19 *$ \\
\hline V & $\%$ & 11.11 & 8.40 & 5.40 & 49.50 & 7.59 & 57.66 & 68.34 & 11.17 & 2.99 & $0.26^{*}$ \\
\hline \multicolumn{12}{|c|}{ Depth $0.40-0.60 \mathrm{~m}$} \\
\hline$\overline{\mathrm{pH}}$ & $\mathrm{H}_{2} \mathrm{O}$ & 4.11 & 4.10 & 3.80 & 4.50 & 0.13 & 0.017 & 3.18 & 0.31 & -0.16 & $0.06^{\mathrm{ns}}$ \\
\hline $\mathrm{H}+\mathrm{Al}$ & $\mathrm{mmol} \mathrm{kg}^{-1}$ & 59.55 & 52.00 & 42.00 & 88.00 & 14.43 & 208.09 & 24.23 & -0.53 & 0.87 & $0.13 *$ \\
\hline MO & $\mathrm{g} \mathrm{dm}^{-3}$ & 14.05 & 11.50 & 7.00 & 27.00 & 5.44 & 29.60 & 38.73 & -0.54 & 0.90 & $0.20 *$ \\
\hline $\mathrm{P}$ & $\mathrm{mg} \mathrm{dm}^{-3}$ & 6.50 & 6.00 & 5.00 & 12.00 & 1.78 & 3.17 & 27.41 & 0.23 & 1.06 & $0.14 *$ \\
\hline K & $\mathrm{mmol} \mathrm{kg}{ }^{-1}$ & 1.39 & 1.20 & 0.40 & 4.40 & 0.78 & 0.61 & 56.24 & 3.44 & 1.61 & $0.10 *$ \\
\hline $\mathrm{Ca}$ & $\mathrm{mmol} \mathrm{kg}$ & 3.44 & 3.00 & 2.00 & 13.00 & 1.88 & 3.52 & 54.58 & 10.41 & 2.76 & $0.16^{*}$ \\
\hline $\mathrm{Mg}$ & $\mathrm{mmol} \mathrm{kg}{ }^{-1}$ & 1.98 & 2.00 & 1.00 & 8.00 & 1.18 & 1.38 & 59.21 & 10.44 & 2.64 & $0.09^{\mathrm{ns}}$ \\
\hline SB & $\mathrm{mmol} \mathrm{kg}{ }^{-1}$ & 6.81 & 5.90 & 3.40 & 25.40 & 3.57 & 12.75 & 52.41 & 11.24 & 2.79 & $0.17 *$ \\
\hline $\mathrm{T}$ & $\mathrm{mmol} \mathrm{kg}^{-1}$ & 66.36 & 60.50 & 46.50 & 100.40 & 15.30 & 234.14 & 23.06 & -0.61 & 0.86 & $0.18^{*}$ \\
\hline $\mathrm{V} \%$ & $\%$ & 10.34 & 9.00 & 5.50 & 37.70 & 4.97 & 24.73 & 48.11 & 14.01 & 3.11 & $0.20 *$ \\
\hline
\end{tabular}

Un.: Unit; SD: Standard Deviation; Var.: Variance; CV: Coefficient of Variation; Kurt.: Kurtosis; Asyim.= Coefficient of Asymmetry; d: test of Normality, *significant by the test of Kolmogorov-Smirnov. 
Through the analysis of semivariograms it is observable, in both areas, that $\mathrm{pH}$ was the attribute of soil which presented the smaller nugget effect when compared to remaining chemical attributes studied, and also the smaller CV (Table 3 and 4). In this way, through descriptive statistical methods and geostatistics, it is possible to predict soil attributes which variability values were not detected by the sampling scheme, because of greater discontinuity between samples. According to Cavalcante et al. (2007), denser samplings may reveal greater spatial continuity of the analyzed chemical attributes.

The Degree of Spatial Dependence (DSD), expressed by the ratio between nugget effect $\left(C_{0}\right)$, and sill $\left(C_{0}+C_{l}\right)$ (CAMBARDELLA et al., 1994), was classified as moderate for most of the studied chemical attributes in the IBE area, while, in forest area, strong DSD predominance is observable (Table 3 and 4). According to Cambardella et al. (1994), variables with strong spatial dependence are more influenced by intrinsic soil properties, that is to say by factors related to soil formation, whereas moderate spatial dependence would be due to soil homogenization, as the extrinsic factors are considered with weak dependence.

Table 3. Models and estimated parameters of semivariograms of chemical attributes in IBE area in the region of Manicoré, AM.

Tabela 3. Modelos e parâmetros estimados dos semivariogramas dos atributos químicos em área de TPI na região de Manicoré, AM.

\begin{tabular}{|c|c|c|c|c|c|c|c|}
\hline Attributes & Unit & Model & $C_{0}$ & $C_{0}+C_{1}$ & $a(\mathbf{m})$ & $\mathbf{R}^{2}$ & DSD \\
\hline \multicolumn{8}{|c|}{ Depth $0.0-0.20 \mathrm{~m}$} \\
\hline $\mathrm{pH}$ & $\mathrm{H}_{2} \mathrm{O}$ & Sph & 0.0235 & 0.0555 & 32.7 & 0.65 & 0.423 \\
\hline $\mathrm{H}+\mathrm{Al}$ & $\mathrm{mmol} \mathrm{kg}{ }^{-1}$ & Sph & 7.21 & 31.92 & 22.6 & 0.87 & 0.226 \\
\hline MO & $\mathrm{g} \mathrm{dm}^{-3}$ & Sph & 38.4 & 117 & 33.1 & 0.77 & 0.328 \\
\hline $\mathrm{P}$ & $\mathrm{mg} \mathrm{dm}^{-3}$ & PNE & - & - & - & - & - \\
\hline $\mathrm{K}$ & $\mathrm{mmol} \mathrm{kg}{ }^{-1}$ & Sph & 0.063 & 0,2 & 23.86 & 0.94 & 0.315 \\
\hline $\mathrm{Ca}$ & $\mathrm{mmol} \mathrm{kg}{ }^{-1}$ & Sph & 215 & 589 & 31 & 0.94 & 0.365 \\
\hline $\mathrm{Mg}$ & $\mathrm{mmol} \mathrm{kg}{ }^{-1}$ & Sph & 16.7 & 38.94 & 35.04 & 0.54 & 0.429 \\
\hline SB & $\mathrm{mmol} \mathrm{kg}{ }^{-1}$ & Exp & 318 & 853 & 40.2 & 0.61 & 0.373 \\
\hline $\mathrm{T}$ & $\mathrm{mmol} \mathrm{kg}{ }^{-1}$ & Sph & 1.00 & 402 & 22.3 & 0.96 & 0.002 \\
\hline $\mathrm{V}$ & $\%$ & Sph & 4.07 & 8.66 & 44.4 & 0.96 & 0.47 \\
\hline \multicolumn{8}{|c|}{ Depth $0.40-0.60 \mathrm{~m}$} \\
\hline $\mathrm{pH}$ & $\mathrm{H}_{2} \mathrm{O}$ & Sph & 0.039 & 0.098 & 24.2 & 0.73 & 0.398 \\
\hline $\mathrm{H}+\mathrm{Al}$ & $\mathrm{mmol} \mathrm{kg}{ }^{-1}$ & Sph & 11.64 & 32.08 & 26.3 & 0.77 & 0.363 \\
\hline MO & $\mathrm{g} \mathrm{dm}^{-3}$ & Exp & 12.22 & 25.18 & 40 & 0.51 & 0.485 \\
\hline $\mathrm{P}$ & $\mathrm{mg} \mathrm{dm}{ }^{-3}$ & Sph & 1754 & 4716 & 59.1 & 0.96 & 0.372 \\
\hline $\mathrm{K}$ & $\mathrm{mmol} \mathrm{kg}{ }^{-1}$ & Sph & 0.0054 & 0.10 & 23.7 & 0.96 & 0.053 \\
\hline $\mathrm{Ca}$ & $\mathrm{mmol} \mathrm{kg}{ }^{-1}$ & Sph & 101.2 & 208.1 & 40 & 0.97 & 0.486 \\
\hline $\mathrm{Mg}$ & $\mathrm{mmol} \mathrm{kg}{ }^{-1}$ & Sph & 2.69 & 8.26 & 20.6 & 0.43 & 0.326 \\
\hline SB & $\mathrm{mmol} \mathrm{kg}{ }^{-1}$ & Exp & 58.00 & 586.2 & 36.3 & 0.91 & 0.099 \\
\hline $\mathrm{T}$ & $\mathrm{mmol} \mathrm{kg}{ }^{-1}$ & Sph & 264.5 & 571 & 50.3 & 0.91 & 0.463 \\
\hline $\mathrm{V}$ & $\%$ & Sph & 11.59 & 35.747 & 25.13 & 0.51 & 0.324 \\
\hline
\end{tabular}

The range of spatial dependence is an important parameter of the semivariogram since indicates the influence zone of a sample, that is to say the value of this parameter indicates a radius where values within it present great similarity and are correlated. The greatest and smallest range values of the variability models were 44.4 and $22.3 \mathrm{~m}$ at $0.0-0.20 \mathrm{~m}$ depth and 59.1 and 23.7 at $0.40-0.60 \mathrm{~m}$ depth in the IBE area. In native forest, at $0.0-0.20 \mathrm{~m}$ depth, values were 73.0 and $25.1 \mathrm{~m}$ and at $0.40-0.60 \mathrm{~m}$ depth were 92.0 and $50.16 \mathrm{~m}$, respectively (Tables 4 and 5). All range values were greater than planned for the grid and were in accordance with Souza et al. (2007).

These range values provide information about heterogeneity of spatial distribution of the studied properties in each management system (TRANGAMAR et al., 1985). The forest area revealed range 
values of the spatial variability structure of the chemical attributes greater than values found the IBE area, indicating much more homogenous distribution of these attributes in the native forest area.

Hence, using the coefficient of variation when studying variability of soil attributes allows to calculate the minimum number of sub-samples needed to estimate the value of an attribute in a given area. Thus, using the formula proposed by Cline (1944), the minimum number of samples needed to estimate chemical attributes of both areas is determinable (Table 5). In the same way, geostatistics based on the "range" parameter also allows to estimate the minimum number of samples to properly determine the soil attributes (Table 6).

Table 4. Models and estimated parameters of semivariograms of chemical attributes in native florest area in the region of Manicoré, AM.

Tabela 4. Modelos e parâmetros estimados dos semivariogramas dos atributos físicos em área de floresta nativa na região de Manicoré, AM.

\begin{tabular}{|c|c|c|c|c|c|c|c|}
\hline Attributes & Unit & Model & $C_{0}$ & $C_{0}+C_{1}$ & $a(\mathbf{m})$ & $\mathbf{R}^{2}$ & DSD \\
\hline \multicolumn{8}{|c|}{ Depth $0.0-0.20 \mathrm{~m}$} \\
\hline $\mathrm{pH}$ & $\mathrm{H}_{2} \mathrm{O}$ & Sph & 0.01 & 0.03 & 38.70 & 0.97 & 0.319 \\
\hline $\mathrm{H}+\mathrm{Al}$ & $\mathrm{mmol} \mathrm{kg}{ }^{-1}$ & Sph & 131.00 & 594.20 & 72.70 & 0.98 & 0.220 \\
\hline MO & $\mathrm{g} \mathrm{dm}^{-3}$ & Sph & 7.60 & 51.27 & 63.50 & 0.98 & 0.148 \\
\hline $\mathrm{P}$ & $\mathrm{mg} \mathrm{dm}^{-3}$ & Sph & 0.70 & 3.81 & 25.10 & 0.59 & 0.185 \\
\hline $\mathrm{K}$ & $\mathrm{mmol} \mathrm{kg}{ }^{-1}$ & Sph & 0.24 & 0.652 & 31.80 & 0.58 & 0.367 \\
\hline $\mathrm{Ca}$ & $\mathrm{mmol} \mathrm{kg}{ }^{-1}$ & Sph & 0.08 & 1.70 & 41.70 & 0.94 & 0.049 \\
\hline $\mathrm{Mg}$ & $\mathrm{mmol} \mathrm{kg}{ }^{-1}$ & Sph & 0.69 & 1.67 & 55.70 & 0.89 & 0.417 \\
\hline SB & $\mathrm{mmol} \mathrm{kg}{ }^{-1}$ & Exp & 1.52 & 13.87 & 48.00 & 0.96 & 0.110 \\
\hline $\mathrm{T}$ & $\mathrm{mmol} \mathrm{kg}{ }^{-1}$ & Sph & 75.00 & 598.00 & 73.00 & 0.98 & 0.125 \\
\hline $\mathrm{V}$ & $\%$ & Exp & 3.70 & 14.62 & 35.70 & 0.76 & 0.253 \\
\hline \multicolumn{8}{|c|}{ Depth $0.40-0.60 \mathrm{~m}$} \\
\hline $\mathrm{pH}$ & $\mathrm{H}_{2} \mathrm{O}$ & Exp & 0.0009 & 0.0126 & 50.16 & 0.95 & 0.071 \\
\hline $\mathrm{H}+\mathrm{Al}$ & $\mathrm{mmol} \mathrm{kg} \mathrm{kg}^{-1}$ & Gau & 64.00 & 272.40 & 84.18 & 0.98 & 0.235 \\
\hline MO & $\mathrm{g} \mathrm{dm}^{-3}$ & Sph & 0.10 & 50.31 & 92.00 & 0.99 & 0.002 \\
\hline $\mathrm{P}$ & $\mathrm{mg} \mathrm{dm}^{-3}$ & Sph & 0.01 & 3.87 & 79.20 & 0.95 & 0.003 \\
\hline $\mathrm{K}$ & $\mathrm{mmol} \mathrm{kg}{ }^{-1}$ & PNE & - & - & - & - & - \\
\hline $\mathrm{Ca}$ & $\mathrm{mmol} \mathrm{kg-1}$ & Sph & 0.52 & 1.79 & 72.30 & 0.97 & 0.289 \\
\hline $\mathrm{Mg}$ & $\mathrm{mmol} \mathrm{kg}{ }^{-1}$ & Sph & 0.19 & 1.033 & 60.80 & 0.98 & 0.188 \\
\hline SB & $\mathrm{mmol} \mathrm{kg}$ & Sph & 1.30 & 5.49 & 63.30 & 0.91 & 0.237 \\
\hline $\mathrm{T}$ & $\mathrm{mmol} \mathrm{kg}{ }^{-1}$ & Sph & 1.00 & 342.00 & 78.80 & 0.99 & 0.003 \\
\hline V & $\%$ & PNE & - & - & - & - & - \\
\hline
\end{tabular}

$C_{0}$ : Nugget Effect; $C_{0}+C_{l:}$ Sill; DSD: degree of spatial dependence; $\mathrm{R}^{2}$ : Coefficient of Determination; Exp: exponential; Sph: spherical; Gau: Gaussian; PNE: pure nugget effect.

Thus, considering that the minimum number of soil sub-samples is directly proportional to the coefficient of variation, the greater the $\mathrm{CV}$, the greater will be the number of sub-samples to be collected (SOUZA et al., 2006). In this study was observed that the variables $\mathrm{pH}, \mathrm{T}$ and $\mathrm{V} \%(0.0-0.20 \mathrm{~m}$ and 0.40 $0.60 \mathrm{~m}$ ) for IBE and only pH (0.0-0.20 m and 0.40-0.60 m) (Table 6) for soil under native forest required a smaller number of samples for the same error around mean value, consequently, the other variables for both areas had a greater density than what established in the sampling grid.

Consequently, basing on $\mathrm{CV}$ of the attributes, the means of sampling density were greater when range was smaller than established in the grid for both areas in both assessed depths. On the other hand, using the semivariogram range, diminution is observable in the number of samples to be collected to evaluate all the physical attributes, as per the formula of Cline (Tables 5 and 6). With these data is possible to estimate a range mean value of $31.80 \mathrm{~m}$ and $50.20 \mathrm{~m}$ at $0.0-0.20 \mathrm{~m}$ depth, and 34.50 and $72.50 \mathrm{~m}$ at $0.40-0.60 \mathrm{~m}$ depth, for IBE and native forest, respectively, which could facilitate future studies in IBE areas and forest management areas with similar characteristics to this study. Specifically, 
greater variability is observable at $0.40-0.60 \mathrm{~m}$ for IBE basing on geostatistics, opposite to what found under native forest.

These information may facilitate works in field, since several studies on sampling have been conducted aiming to reduce variability of soil characteristics: influence of the sampling collection instrument (auger, blade, hoe etc.) (GUARÇONI et al., 2007; OLIVEIRA et al., 2007); necessary number of samples to form a composite (BRUS; NOIJ, 2008; WEINDORF; ZHU, 2010); effect of cultural traits (OLIVEIRA et al., 2007; PAULETTI et al., 2009); and effects of landforms (MONTANARI et al., 2005; SANCHEZ et al., 2009). However, these studies generally do not consider variability of the sub-samples to build up the composed sample, neither the way tracts of land are defined.

Table 5. Values of sample density and ideal spacing according to the Cline formula (\% CV) for chemical attributes of IBE and native forest area in the city of Maricoré, AM.

Tabela 5. Valores de densidade amostral e espaçamento ideal de acordo com a fórmula de Cline (CV\%) para os atributos químicos em área de TPA e floresta nativa no Município de Maricoré, AM.

\begin{tabular}{|c|c|c|c|c|}
\hline \multirow{3}{*}{ Attributes } & \multicolumn{4}{|c|}{ Sample planning - CLINE } \\
\hline & \multicolumn{2}{|c|}{ IBE } & \multicolumn{2}{|c|}{ Forest } \\
\hline & $\begin{array}{c}\text { Sample density } \\
\text { (points/ha) }\end{array}$ & Spacing $(\mathbf{m})$ & $\begin{array}{c}\text { Sample density } \\
\text { (points/ha) }\end{array}$ & Spacing (m) \\
\hline \multicolumn{5}{|c|}{ Depth $0.0-0.20 \mathrm{~m}$} \\
\hline $\mathrm{pH}$ & 12 & 29 & 13 & 28 \\
\hline $\mathrm{H}+\mathrm{Al}$ & 304 & 6 & 478 & 5 \\
\hline MO & 218 & 7 & 687 & 4 \\
\hline $\mathrm{P}$ & 430 & 5 & 720 & 4 \\
\hline K & 3738 & 2 & 2496 & 2 \\
\hline $\mathrm{Ca}$ & 143 & 8 & 5737 & 1 \\
\hline $\mathrm{Mg}$ & 268 & 6 & 1412 & 3 \\
\hline SB & 121 & 9 & 2633 & 2 \\
\hline $\mathrm{T}$ & 83 & 11 & 378 & 5 \\
\hline $\mathrm{V}$ & 9 & 33 & 2577 & 2 \\
\hline Mean & 533 & 11 & 1713 & 6 \\
\hline \multicolumn{5}{|c|}{ Depth $0.40-0.60 \mathrm{~m}$} \\
\hline $\mathrm{pH}$ & 16 & 25 & 6 & 42 \\
\hline $\mathrm{H}+\mathrm{Al}$ & 211 & 7 & 324 & 6 \\
\hline MO & 272 & 6 & 828 & 3 \\
\hline $\mathrm{P}$ & 782 & 4 & 415 & 5 \\
\hline K & 11087 & 1 & 1745 & 2 \\
\hline $\mathrm{Ca}$ & 281 & 6 & 1644 & 2 \\
\hline $\mathrm{Mg}$ & 486 & 5 & 1935 & 2 \\
\hline SB & 352 & 5 & 1516 & 3 \\
\hline $\mathrm{T}$ & 188 & 7 & 293 & 6 \\
\hline $\mathrm{V}$ & 45 & 15 & 1277 & 3 \\
\hline Mean & 1372 & 8 & 1142 & 7 \\
\hline
\end{tabular}

\section{CONCLUSIONS}

- The coefficient of variation gave mean sampling densities greater than initially established by the sampling grid, for both areas at both studied depths.

- Mean spatial range of $31.80 \mathrm{~m}$ and $50.20 \mathrm{~m}$ at $0.0-0.20 \mathrm{~m}$ depth and 34.50 and 72.50 at $0.40-0.60$ $\mathrm{m}$ depth for IBE and for soil under native forest, respectively, reveal that for greater distances than the above mentioned, data must be treated as independent. These results suggest that when soil sampling is to be defined, samples can be distant each other up to those distances to be properly treated as spatially dependent.

- These results may assist future studies on spatial variability mapping in IBE and native forest, aiming preservation or sustainable management projects in these areas. 
Table 6. Values of sample density and consequent ideal spacing based on the estimated range in geostatistical analysis for chemical attributes of IBE and native forest area in the city of Maricoré, AM.

Tabela 6. Valores de densidade amostral e espaçamento ideal de acordo com base no alcance estimado na análise geoestatística para os atributos químicos em área de TPA e floresta nativa no município de Maricoré, AM.

\begin{tabular}{|c|c|c|c|c|}
\hline \multirow{3}{*}{ Attributes } & \multicolumn{4}{|c|}{ Sample planning - Geoestatistics } \\
\hline & \multicolumn{2}{|c|}{ IBE } & \multicolumn{2}{|c|}{ Forest } \\
\hline & $\begin{array}{l}\text { Sampling density } \\
\text { (points/ha) }\end{array}$ & Spacing (m) & $\begin{array}{l}\text { Sampling density } \\
\text { (points/ha) }\end{array}$ & Spacing (m) \\
\hline \multicolumn{5}{|c|}{ Depth $0.0-0.20 \mathrm{~m}$} \\
\hline $\mathrm{pH}$ & 9 & 33 & 7 & 39 \\
\hline $\mathrm{H}+\mathrm{Al}$ & 20 & 23 & 2 & 73 \\
\hline MO & 9 & 33 & 2 & 64 \\
\hline $\mathrm{P}$ & 18 & 24 & 10 & 32 \\
\hline $\mathrm{K}$ & 10 & 31 & 6 & 42 \\
\hline $\mathrm{Ca}$ & 8 & 35 & 3 & 56 \\
\hline $\mathrm{Mg}$ & 6 & 40 & 4 & 48 \\
\hline SB & 20 & 22 & 2 & 73 \\
\hline CTC & 5 & 44 & 8 & 36 \\
\hline $\mathrm{V}$ & 9 & 33 & 7 & 39 \\
\hline Mean & 11.4 & 31.80 & 5.1 & 50.2 \\
\hline \multicolumn{5}{|c|}{ Depth $0.40-0.60 \mathrm{~m}$} \\
\hline $\mathrm{pH}$ & 17 & 24 & 4 & 50 \\
\hline $\mathrm{H}+\mathrm{Al}$ & 14 & 26 & 1 & 84 \\
\hline MO & 6 & 40 & 1 & 92 \\
\hline $\mathrm{P}$ & 3 & 59 & 2 & 79 \\
\hline $\mathrm{K}$ & 18 & 24 & - & - \\
\hline $\mathrm{Ca}$ & 6 & 40 & 2 & 72 \\
\hline $\mathrm{Mg}$ & 24 & 21 & 3 & 61 \\
\hline SB & 8 & 36 & 2 & 63 \\
\hline CTC & 4 & 50 & 2 & 79 \\
\hline $\mathrm{V}$ & 16 & 25 & - & - \\
\hline Mean & 11.6 & 34.5 & 2.12 & 72.5 \\
\hline
\end{tabular}

\section{AKNOWLEDGMENTS}

The authors would like to thank Fundação de Amparo à Pesquisa do Estado do Amazonas (FAPEAM), Fundação de Amparo à Pesquisa do Estado do Amazonas (FAPESP) and Universidade Federal do Amazonas (IEAA/UFAM), for financing and supporting this research.

\section{REFERENCES}

BERTOLANI, F. C.; VIEIRA, S. R. Variabilidade espacial da taxa de infiltração de água e da espessura do horizonte A, em um Argissolo Vermelho-Amarelo, sob diferentes usos. Revista Brasileira de Ciência do Solo, Viçosa, v. 25, p. 987 - 995, 2001.

BRASIL. Ministério das Minas e Energia. Projeto Radambrasil, folha SB. 20, Purus. Rio de Janeiro, 1978. $561 \mathrm{p}$.

BRUS, D. J.; NOIJ, I. G. A. M. Designing sampling schemes for effect monitoring of nutriente leaching from agricultural soils. European Journal of Soil Science, Oxford. v. 59, p. 292 - 303, 2008.

CAMBARDELlA, C. A.; MOORMAN, T. B.; NOVAK, J. M.; PARKIN, T. B.; KARLEN, D. L.; TURCO, R. F.; KONOPKA, A. E. Field - scale variability of soil properties in Central Iowa Soil. Soil Science Society of America Journal, Madson, v. 58, p. 1501 - 1511, 1994. 
CAMPOS, M. C. C. Pedogeomorfologia aplicada a ambientes Amazônicos do Médio Rio Madeira. 2009. 260 f. Tese (Doutorado em Ciência do Solo) - Universidade Federal Rural de Pernambuco, Recife, 2009.

CARVALHO, M. P.; TAKEDA, E. Y.; FREDDI, O. S. Variabilidade espacial de atributos de um solo sob videira em Vitório Brasil (SP). Revista Brasileira de Ciência do Solo, Viçosa, v. 27, p. 695 - 703, 2003.

CARVALHO, S. R. L.; VILAS BOAS, G. S.; FADIGAS, F. S.; variabilidade espacial de atributos físicos e químicos em solos originados nos sedimentos da formação barreiras. Cadernos de Geociências, Salvador, v. 7, n. 2, p. $63-79,2010$.

CAVAlCANTE, E. G. S.; ALVES, M. C.; SOUZA, Z. M.; PEREIRA, G. T. Variabilidade espacial de atributos químicos do solo sob diferentes usos e manejos. Revista Brasileira de Ciência do Solo, Viçosa, v. 31, p. 1329 - 1339, 2007.

CLINE, M. G. Principles of soil sampling . Soil Science, Baltimore, v. 58, p. 275 - 288, 1944.

CORTEZ, J. W.; ALVES, A. D. S.; MOURA, M. R. D.; OLSZEVSKI, N.; NAGAHAMA H. J. Atributos físicos do argissolo amarelo do semiárido nordestino sob sistemas de preparo. Revista Brasileira de Ciência do Solo, Viçosa, v. 35, p. 1207 - 1216, 2011.

CRESSIE, N. Statistics for spatial data. New York, John Wiley. 1991. 920 p.

CUNHA, T. J. F.; MADARI, B. E.; BENITES, V. M.; CANELAS, L. P.; NOVOTNY, E. H.; MOUTTA, R. O.; TROMPOWSKY, P.; SANTOS, G. A. Fracionamento químico da matéria orgânica e características de ácidos húmicos de solos com horizonte A antrópico da Amazônia (Terra Preta). Acta Amazônica, Manaus, v. 37, p. 91 - 98, 2007.

EMPRESA BRASILEIRA DE PESQUISA AGROPECUÁRIA (EMBRAPA). Centro Nacional de Pesquisa de Solos. Manual de métodos de análise de solo. Rio de Janeiro, 2011. 230 p.

EMPRESA BRASILEIRA DE PESQUISA AGROPECUÁRIA (EMBRAPA). Centro Nacional de Pesquisa de Solos. Sistema Brasileiro de Classificação de Solos. 3.ed. revisada e ampliada. Brasília. 2013. 353p.

GLASER, B. Prehistorically modified soils of central Amazonia: a model for sustainable agriculture in the twenty-first century. Philosophical Transactions of the Royal Society B, Londres, v. 362, p. 187 - 196, 2007.

GLASER, B.; GUGGENBERGER, G.; ZECH, W. Identifying the pre-Columbian anthropogenic input on present soil properties of Amazonian Dark Earths (Terra Preta). In: Amazonian Dark Earths: Explorations in Space and Time. Springer, Berlin, 2004, p. 145 - 158.

GUARÇONI M., A.; ALVAREZ V., V. H.; NOVAIS, R. F.; CANTARUTTI, R. B.; LEITE, H. G.; FREIRE, F. M. Diâmetro de trado necessário à coleta de amostra num Cambissolo sob plantio direto ou sob plantio convencional antes ou depois da aração. Revista Brasileira de Ciência do Solo, Viçosa, v. 31, p. 947 - 959, 2007.

ISAAKS, E. H.; SRIVASTAVA, R. M. An introduction to applied geoestatistics. New York: Oxford University Press, 1989. 561 p.

KAMPF, N.; KERN, D. C. O solo como registro da ocupação humana pré-histórica na Amazônia. In: Tópicos em Ciência do solo. 1 ed. Viçosa: Sociedade Brasileira de Ciência do Solo, 2005, p. 277 - 320.

KERN, D. C.; KÄMPF, N. Antigos assentados indígenas na formação de solos com Terra Preta Arqueológica na região de Oriximiná, Pará. Revista Brasileira de Ciência do Solo, Viçosa, v. 13, p. 219 - 225, 1989.

LARK, R. M. Designing sampling grids from imprecise information on soil variability, an approach based on the fuzzy kriging variance. Geoderma, Amsterdan, v. 98, p. 35 - 39, 2000.

LEHMANN, J.; KERN, D. C.; GLASER, B.; WOODS, W. I. (Eds.), Amazonian Dark Earths: Origin, Properties, Management. Kluwer Academic Publishers, Dodrecht, 2003. 523 p.

MATHERON, G. Principles of geostatistics. Economic Geology, Littleton, v. 58, p. 1246 - 1266, 1963.

MINASNY, B.; McBRATNEY, A. B. Incorporating taxonomic distance into spatial prediction and digital mapping of soil classes. Geoderma, Amsterdan, v. 142, p. 285 - 293, 2007.

MONTANARI, R.; MARQUES JÚNIOR, J.; PEREIRA, G. T.; SOUZA, Z. M. Forma da paisagem como critério para otimização amostral de latossolos sob cultivo de cana-de-açúcar. Pesquisa Agropecuária Brasileira, Viçosa, v. 40, p. 69 - 77, 2005.

OLIVEIRA, F. H. T.; ARRUDA, J. A.; SILVA, I. F.; ALVES, J. C. Amostragem para avaliação da 
fertilidade do solo em função do instrumento de coleta das amostras e de tipos de preparo do solo. Revista Brasileira de Ciência do Solo, Viçosa, v. 31, p. 973 - 983, 2007.

PAULETTI, V.; MOTTA, A. C. V.; SERRAT, B. M.; FAVARETTO, N.; ANJOS, A. Atributos químicos de um Latossolo Bruno sob sistema de plantio direto em função da estratégia de adubação e do método de amostragem de solo. Revista Brasileira de Ciência do Solo, Viçosa, v. 33, p. 581 - 590, 2009.

PETERSEN, J. B.; NEVES, E. G.; HECKENBERGER, M. J. Gift from the past. Terra preta and prehistoric Amerindian occupation in Amazonia. In: Unknown Amazonia. The British Museum Press, London, 2001, p. 86 - 105.

ROBERTSON, G. P. GS+ geostatistics for the environmental sciences: GS+ user's guide. Plainwell: Gamma Design Software, 1998, 152 p.

SALVIANO, A. A. C.; VIEIRA, S. R.; SPAROVEK, G. Variabilidade espacial de atributos de solo e de Crotalaria juncea L. em área severamente erodida. Revista Brasileira de Ciência do Solo, Viçosa, v. 22, p. $115-122,1998$.

SANCHEZ, R. B.; MARQUES JÚNIOR, J.; SOUZA, Z. M.; PEREIRA, G. T.; MARTINS FILHO, M. V. Variabilidade espacial de atributos do solo e de fatores de erosão em diferentes pedoformas. Bragantia, Campinas, v. 68, p. 1095 - 1103, 2009.

SOUZA, Z. M.; BARBIERI, D. M.; MARQUES JÚNIOR, J.; PEREIRA, G. T.; CAMPOS, M. C. C. Influência da variabilidade espacial de atributos químicos de um latossolo na aplicação de insumos para cultura de cana-de-açúcar. Ciência e Agrotecnologia, Lavras, v. 31, p. 371 - 377, 2007.

SOUZA, Z. M.; MARQUES JÚNIOR, J.; PEREIRA, G. T.; MONTANARI, R.; CAMPOS, M. C. C. Amostragem de solo para determinação de atributos químicos e físicos em área com variação nas formas do relevo. Científica, Jaboticabal, v. 34, p. 249 - 256, 2006.

TRANGMAR, B. B.; YOST, R. S.; UEHARA, G. Application of geostatistics to spatial studies of soil properties. Advances in Agronomy, v. 38, p. 54 - 94, 1985.

VAN GROENIGEN, J. W.; SIDERIUS, W.; STEIN, A. Constrained optimisation of soil sampling for minimisation of the kriging variance. Geoderma, Amsterdan, v. 87, p. 239 - 259, 1999.

VIEIRA, S. R.; BRANCALIÃO, S. R.; GREGO, C. R.; MARTINS, A. L. M. Variabilidade Espacial de atributos físicos de um Argissolo Vermelho-Amarelo cultivado com Leguminosas as Consorciados com Seringueira. Bragantia, Campinas, v. 69, p. 423 - 432, 2010.

VIEIRA, S. R.; DECHEN, S. C. F.; SIQUEIRA, G. M.; DUFRANC, G. Variabilidade espacial de atributos físicos e químicos relacionados com o estado de agregação de dois Latossolos cultivados no sistema de semeadura direta. Bragantia, Campinas, v. 70, p. 185 - 195, 2011.

VIEIRA, S. R.; Geoestatística em estudo da variabilidade espacial do solo. In: Tópicos ciência do solo Campinas: Sociedade Brasileira de Ciência do Solo, 2000. p. 1 - 54.

VIEIRA, S. R.; HATFIELD, J. L.; NIELSEN, D. R.; BIGGAR, J. W. Geoestatiscal theory and application to variability of some agronomical properties. Hilgardia, Berkeley, v. 51, p. 1 - 75, 1983.

WARRICK, A. W.; NIELSEN, D. R.; Spatial variability of soil physical properties in the field. In: HILLEL, D. (Ed.). Applications of soil physics. New York, 1980. p. 319 - 344.

WEBSTER, R.; OLIVER, M. A. Statistical methods in soil and land resource survey. Oxford: Oxford University Press, 1990. 316 p.

WEINDORF, D. C.; ZHU, Y. Spatial variability of soil properties at Capulin volcano, New Mexico, USA: implications for sampling strategy. Pedosphere, Nanjing, v. 20, p. 185 - 197, 2010.

WOJCIECHOWSKI, J. C.; SCHUMACHER, M. V.; PIRES, C. A. F.; MADRUGA, P. R. A.; KILCA, R. V.; BRUN, E. J.; SILVA, C. R. S.; VACCARO, S.; RONDON NETO, R. M. Geoestatística aplicada ao estudo das características físico-químicas do solo em áreas de floresta estacional decidual. Ciência Florestal, Santa Maria, v. 19, p. 383 - 391, 2009.

WOODS, W. I., TEIXEIRA, W. G., LEHMANN, J.; STEINER, C.; WINKLERPRINS, A. M. G. A., REBELLATO, L. (Eds.), Amazonian Dark Earths: Wim Sombroeks Vision. Springer, Berlin, 2009. 502 p.

YEOMANS, J. C.; BREMNER, J. M. A rapid and precise method for routine determination of organic carbon in soil. Communication in Soil Science and Plant Analysis. v. 19, p. 1467 - 1476, 1988. 